\title{
Congenital Listeriosis
}

National Cancer Institute

\section{Source}

National Cancer Institute. Congenital Listeriosis. NCI Thesaurus. Code C116807.

A bacterial infection by Listeria monocytogenes that is present at birth. 